\title{
A real sting in the tail: five years on
}

Cite as: CMAJ 2020 August 10;192:E931-2. doi: 10.1503/cmaj.200316

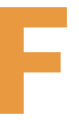

ive years ago, I underwent extensive surgery in the uncertain hope of ridding my pelvis of a "highgrade" prostatic tumour. My father and paternal grandfather had been felled before their time by the same curse. I wrote about events in the first 6 months, $, 1,2$ describing a difficult early course while making some suggestions about improving care. Alive and well in 2020, I look back over half a decade to balance the benefits and costs of key decisions along a rather atypical journey - in other words, was it all worth it?

After those first reflections were published, $, 1,2$ received unsolicited invitations to talk at provincial and national conferences. The warmth of responses astonished me. There were handshakes and hugs, in particular from female physicians, for a man talking about things that men do not discuss. Perhaps I had put too much out there but, on rereading the stories and reliving events, "je ne regrette rien."

Time passed. Family and friends looked to me to advise loved ones on prostaterelated investigations and operations. I did so where my experiences might be relevant, while cognizant that mine was not a typical experience and events that I described might not apply to others. In this context, two new long-term friendships were born. One was in the United Kingdom with a happily married ex-rugby-playing septuagenarian; we still enjoy laughing over pints while discussing our current realities. In a recent wonderful example of hope springs eternal, he mentioned looking forward to a prescription for a new erectile dysfunction-related lotion and whether, at some suitable weekend away with his wife, maybe .... Kerpung!

Again in the UK, friendships with old school friends have been rekindled, leading to delightful brunches and dinners, timed to coincide with matches at the

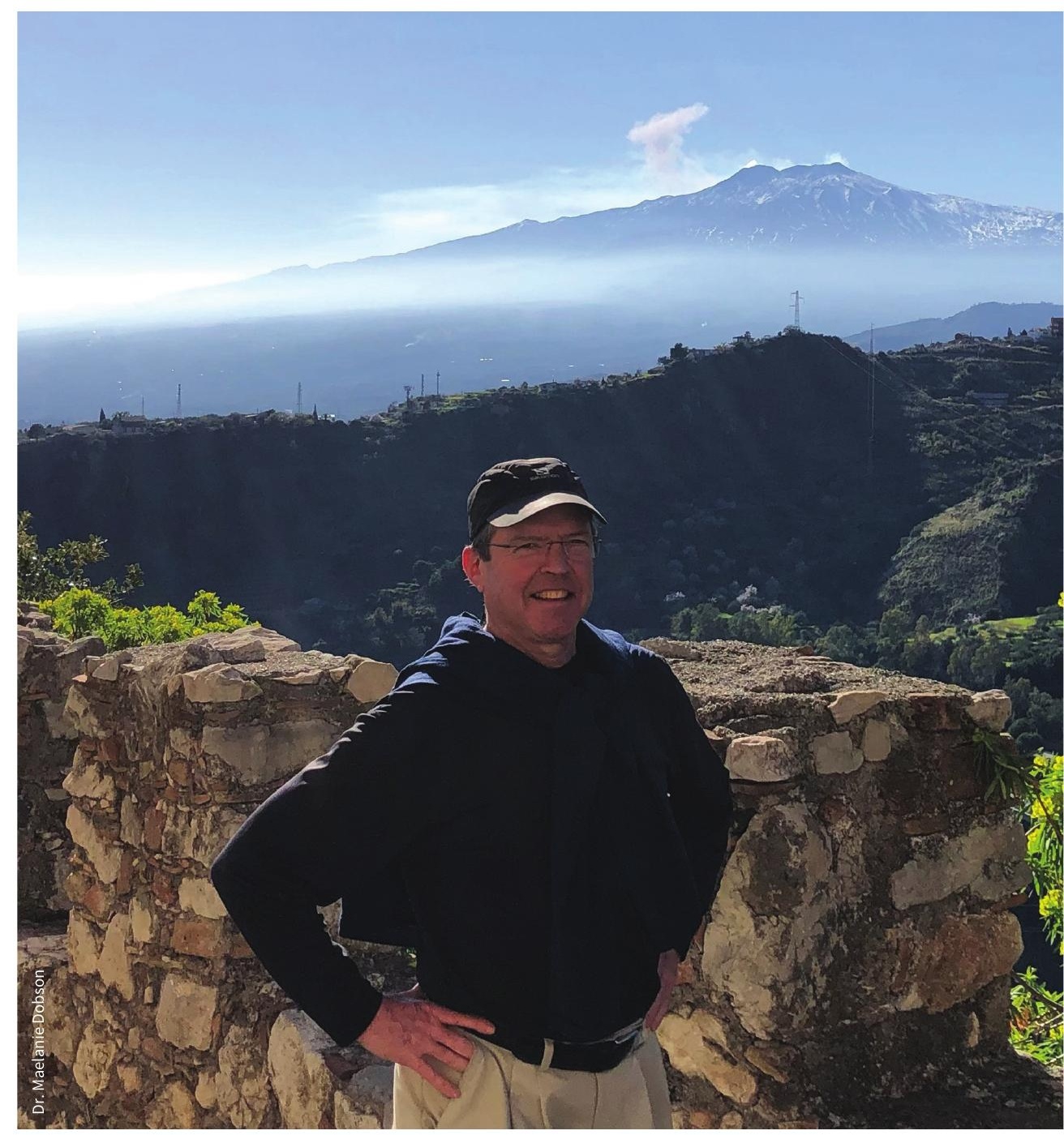

Dr. Graeme Rocker at Mount Etna, Italy.

magnificent new Tottenham Hotspur (Spurs) stadium in North London.

One of my UK medical school chums, now a near-retirement specialist, had endured a tortuous time after a more recent prostatectomy in which everything that could go wrong did, even in his esteemed university hospital. Subsequently, he had a recurrence in the prostate bed. We should take nothing for granted. I had a similar recurrence.
We both had to endure 33 sessions of radiotherapy, an unhappy challenge. Three years ago, with a blip in my prostate-specific antigen (PSA), a biochemical recurrence came as a stark reminder of my mortality. After an magnetic resonance imaging (MRI) scan had refuted the earlier somewhat concerning computed tomography (CT) report that suggested a secondary deposit (it was a remnant of a seminal vesicle) and sensing 
indecision on my part, my radiation oncologist simply said, "Why wait?"

I did not wait but, with some embarrassment, stumbled at the first hurdle. To minimize any radiation injury a pelvic "fry" requires a full bladder and an empty colon. Sadly, I lacked the skill to keep a full bladder while expelling some gas and was sent away to refill! Attending 33 daily sessions gets tedious, as does being asked each time to give full name and date-of-birth (a policy to ensure rays reach the right person). Set against other more aggressive treatments elsewhere, I should have been more compliant, but I struggled with surrendering yet another modicum of personal control. Time passed faster with Pink Floyd on the sound system. Some days I would bring my own music, often listening quietly to Richard Strauss' Death and Transfiguration, which somehow seemed apt.

Ultimately, I neared the end of radiotherapy. My radiation oncology physician authorized two sessions a day for a couple of days in the last week. Why? So I could get to a Premier League game in London as per my request! My wife (who knows all about DNA repair at a molecular (evel) was appalled, but then she is a much more recent Spurs fan. On my last day, I handed out chocolates to the radiation team. There were hugs, especially for one woman whose gentle hand on my shoulder as I entered the machine was a welcome reminder that health care should be about caring.

No day goes by without fleeting reminders of the physical consequences of missing nerves. Every shower, every bathroom trip is a minor rerun of that wonderful Seinfeld "shrinkage" episode 3 when George and his lady friend discover the consequences of a cold-water swim. In the absence of a blood supply to erectile tissue, that tissue withers on the vine! Like George, we just need to get over it or embrace penile health as promoted by some clinics!

I described in my earlier blog posts eschewing opportunities to use a plastic vacuum pump that would bring blood back under negative pressure. Others, in similar circumstances, go that route. I do recall with crystal clarity the conversation with my urologist on day one, when he said with some confidence that, "He was going for a cure." He was quite clear about the downside. "There would be no more erections." So it has proved. Some men never do get over it. There is much depression among patients after prostate surgery. I have been lucky in that regard (the mental health side of things), though I did dip sometimes into dark spaces early on. This could probably be offset if men took a lead from women and talked to fellow travellers about these things.

I hear and sometimes read about advances in prostate cancer care. No one should go through unnecessary biopsies or surgery. New techniques offer less chance of incontinence and the dreaded specter of impotence, but only time will tell if preserving this aspect of being male is the gold standard rather than a radical approach to cure. I wrote in an earlier blog post about what for me were some absurdities ("have you tried a feather duster?"). Who knew it would take three and a half years for the painful orgasm-related, electric shocklike sensation in my rectum to dissipate? Did my severed nerves find a new place to attach? How common is this - who talks about such things?

More important, though, in all of this has been the wonderful support of my sons and especially my brilliant wife. I must have been hell to live with in the early stages, and on and off since, but we are enjoying life and love, and fine ends to our professional careers within our "new equilibrium." The marital bed is still a happy place, which makes the point that while the male of the species places much value upon a traditional attribute, their female partner, especially in longstanding relationships, is quite likely to be more desirous of feelings of intimacy. I hope this is something to encourage other similarly fated men. When my wife and I emerge from isolation related to coronavirus disease 2019 (COVID-19), there are enticing prospects of travel along special railway lines in England or where my nascent Italian takes us. I recently took some classes and then rediscovered Italy itself after an absence of 30 years. I am hooked.

So, five years on, with recent undetectable PSA and with no need, as yet, for antiandrogen therapy, I am told that I am living the dream. I enjoyed lunches and coffees with local colleagues and friends before COVID-19. I have long shared Sir Rod Stewart's passion for model trains. ${ }^{4}$ On a smaller scale, I have recreated the tracks, stations, fields and steam trains of my early childhood, near the London to Birmingham main line, and delight in the landscaping skills I have acquired over many years.

Close to home in Halifax, I walk the local trails and greet the dogs. I enjoy each summer mile astride my more than 40-year-old Moto Guzzi. I have stepped aside from a provincial leadership role with the INSPIRED COPD [chronic obstructive pulmonary disease] Outreach Program (www. nshealth.ca/content/inspired-copd-outreach -program), treasure memories and friendships from a long and varied career, and had a lovely retirement bash recently. Life is not a dress rehearsal. Uncertainty builds around each six-month PSA check, uncertainty that is typical of hypervigilant cancer survivors, but so far, so good. Without my esteemed specialists in urology and radiation oncology where would I be now? Not on the right side of the grass for sure. They pushed me to make bold decisions about treatment that were not options for my father and grandfather. ${ }^{1}$ I could not have made those decisions alone and I am eternally grateful. Yes, without doubt, it was all worth it.

\section{Graeme M. Rocker DM}

Division of Respirology, Queen Elizabeth II Health Sciences Centre, Halifax, NS

\section{References}

1. Rocker GM. A real sting in the tail. CMAJ 2015 187:440-1.

2. Rocker G. Category: Graeme Rocker [blogs]. Ottawa: Canadian Medical Association; 2015. Available: https://cmajblogs.com/category/patients -blog/graeme-rocker/ (accessed 2020 Apr. 28).

3. "The Hamptons." Seinfeld [TV show], season 5, episode 21, National Broadcasting Company, aired 1994, May 12.

4. I am railing: Sir Rod Stewart reveals his epic model railway city. BBC News 2019 Nov. 13. Available: www.bbc.com/news/entertainment -arts-50403561 (accessed 2020 Apr. 28)

This article has been peer reviewed.

Acknowledgements: Beyond many supportive friends and colleagues, I would also like to extend special thanks to my esteemed specialists, Drs. Ricardo Rendon and David Bowes who, while modestly claiming they were just doing their job, did much more than that. They cared and gave me hope.

The author's friends and his wife have all given their consent to appear in this narrative. 